\title{
CIÊNCIANATURA
}

\section{Evaluation of intestinal histological damage in zebrafish exposed to environ- mentally relevant concentrations of manganese}

\author{
Gabriela Zimmermann Prado Rodrigues, Mateus Santos de Souza, Antonia Homrich da Silva, Bruna \\ Graziela Zwetsch, Günther Gehlen \\ Universidade Feevale, RS Brasil
}

\begin{abstract}
Manganese is an essential element for many physiological processes. However, in prolonged exposures or at high concentrations it may present toxicity to several organs, which has made it an object of study in pharmacological, behavioral, neurological and environmental research in different organisms. Thus, it was aimed to evaluate the damage caused by acute and chronic exposures to this element, through the histopathological analysis of the zebrafish (Danio rerio) intestine. Samples were embedded in paraffin for further processing in rotating microtome, and the slides were stained with Alcian Blue and hematoxylin for observation and analysis under light microscopy. The results demonstrated the potential of the metal to cause histological changes in this organ, such as fusion of villi (in 0.5 and $4.0 \mathrm{mg} \mathrm{L}^{-1}$ ), and to increase by more than $50 \%$ the number of goblet cells (in 8.0 and 16 $m g L^{-1}$ ) in the region analyzed, mainly in the highest concentrations of Manganese Chloride and in chronic exposures, characterizing a possible inflammation of the intestinal epithelium. Thus, the histological analysis of intestines demonstrated to be a reliable alternative for the toxicological evaluation. It is important to monitor the concentrations of this and other metals in the water bodies, given their toxicity.
\end{abstract}

Keywords: Danio rerio; Histopathology; Toxicity; Metals

\section{Resumo}

O manganês é um elemento essencial para inúmeros processos fisiológicos, no entanto, em exposições prolongadas ou a elevadas concentrações pode apresentar toxicidade para diversos órgãos, motivo que o tornou objeto de estudo em pesquisas farmacológicas, comportamentais, neurológicas e ambientais em diferentes espécies de organismos. Assim, objetivou-se avaliar o dano causado por exposições aguda e crônica a este elemento, através da análise histopatológica do intestino de peixe-zebra (Danio rerio). As amostras foram incluídas em parafina para posterior processamento, e as lâminas foram coradas com Azul de Alcian e hematoxilina para observação e análise em microscopia óptica. Os resultados demonstram a capacidade do metal em causar alterações histológicas neste órgão, como fusão de vilosidades (em 0.5 e $4.0 \mathrm{mg} \mathrm{L^{-1 }}$ ), e aumentar em mais de $50 \%$ o número de células caliciformes (em 8.0 e $16 \mathrm{mg} \mathrm{L}^{-1}$ ) na região analisada, principalmente nas mais elevadas concentrações de Cloreto de Manganês, e após exposição crônica, caracterizando uma possível inflamação do epitélio intestinal. Assim a análise histológica de intestinos demonstrou ser uma alternativa confiável para avaliação toxicológica. Destaca-se a importância do monitoramento das concentrações deste e outros metais nos corpos hídricos, dado a sua toxicidade.

Palavras-chave: Danio rerio; Histopatologia; Toxicidade; Metais 


\section{Introduction}

Studies on pollutants that are able to interfere at the hydric resources quality and its respective organisms are essential for the control and public awareness of the environmental pollution (DALZOCHIO et al., 2017). Heavy metals are among the substances studied which are usually found at the hydric bodies. They are a matter of concern because of the inability of the conventional treatment systems in removing them from the water (HARIKUMAR and NASIR 2010). The presence of these substances in the aquatic ecosystems is due to natural interactions between water, sediments and atmosphere (SANKAR et al., 2006), but their anthropogenic sources are diverse, including industrial and domestic wastewater, storm drainages, leaching of landfills and atmospheric particles (NAIR et al., 2006). Therefore, studies that evaluate the toxicity of each metal are tools that allow a better evaluation of the synergistic effects that occur in the organisms when there is a variable amount of substances mixed, as occurs in rivers and other hydric bodies.

Regardless of source, the presence of metals in water causes concern due to its persistence, toxicity and bioaccumulation capacity in aquatic organisms (ISLAM et al., 2015; AHMED et al., 2015) and plants (SALAWU et al., 2018). Such substances, in an isolated way, have been reported in studies using zebrafish (Danio rerio), as causes of histopathological (RENIERI et al., 2017), behavioral (NABINGER et al., 2018), reproductive and genotoxic lesions (HUREM et al., 2018), so this species is recognized as a good indicator of toxicity.

Manganese, an example of these substances, is a natural element, essential for diverse physiologic processes, including metabolism of amino acids, lipids, proteins and carbohydrates (ERIKSON et al., 2005), immunologic system, regulation of cell energy, growth of the bone and connective tissue, blood clotting (ERIKSON and ASCHNER, 2003), and for some enzymes related to the synthesis and metabolism of neurotransmitters (GOLUB et al., 2005). However, at high concentrations or prolonged exposure periods, it shows toxicity for different organs in a wide spectrum of animals (ZHANG et al., 2003; ALTENHOFEN et al., 2017; CARVALHO et al., 2018). Its occurrence in aquatic environments may be caused by anthropogenic activities as well, especially in regions near to the industries responsible for the manufacture of iron and steel, use of fertilizers, fungicides and animal supplementation (PATIL et al., 2016). Thereby, it has been a target of environmental researches, by a lot of groups of researchers (RIETZLER et al., 2001; OLIVEIRA et al., 2008; HERMES et al., 2013; SMITH et al., 2014; SUBOTIĆ et al., 2015). Given the scarcity of information about the toxicity of this metal to organisms intestine, essential organ for absorption of nutrients, the aim of this study was to evaluate histopathological alterations in zebrafish (Danio rerio) intestines after acute and chronic expositions to manganese chloride $\left(\mathrm{MnCl}_{2}\right)$.

\section{Materials and Methods}

All the methodological procedures performed in this study occurred according to the predicted and established by the Ethics Committee on the Use of Animals (CEUA) of Feevale University in protocol $n^{\circ} 02.16 .046$.

A solid manganese chloride $\left(\mathrm{MnCl}_{2}\right)$ reagent $(\mathrm{LabSynth} \AA$, purity $98 \%)$ was used for the preparation of the dilutions to be tested. The concentrations used varied from $0.5 \mathrm{mg} \mathrm{L}^{-1}$ [limit established for Class 3 waters, destined to the supply for human consumption after conventional or advanced treatment, by the National Council of the Environment (CONAMA) through Resolution 357/ 2005](BRASIL, 2005), and continue increasing up to $16.0 \mathrm{mg} \mathrm{L}^{-1}$, where $11 \mathrm{mg} \mathrm{L}^{-1}$ is the NOAEL (dose that has no effects) for this element, for humans (WHO, 2003).

Danio rerio were obtained from a local supplier. Reconstituted water was used for maintenance and exposure of animals (ISO, 1996). Fish were acclimated under laboratory conditions for 07 days (before acute and chronic experiments) at a temperature of 26 $\pm 2^{\circ} \mathrm{C}$ and $\mathrm{pH}$ at 7.0 - 8.0, with a maximum density of 5 animals per liter of water, being submitted to a day/night cycle of 10:14 $\mathrm{h}$ (lights on at 7:00 am), in constant aeration, and were fed thrice per day commercial flake food (Alcon). During all proceedings the animals were kept under the same conditions. For the acute experiment the animals were exposed ( $\mathrm{n}=7$ per group) to different concentrations of $\mathrm{MnCl}_{2}\left(0.5 \mathrm{mg} \mathrm{L}^{-1}, 1.0 \mathrm{mg} \mathrm{L}^{-1}, 2.0 \mathrm{mg} \mathrm{L}^{-1}, 4.0 \mathrm{mg} \mathrm{L}^{-1}, 8.0 \mathrm{mg} \mathrm{L}^{-1}\right.$ and $\left.16.0 \mathrm{mg} \mathrm{L}^{-1}\right)$ and reconstituted water, being this group considered the negative control. After 96 hours of exposure, the fish were sacrificed to remove the intestine from each animal. The samples were fixed in formalin, dehydrated in a graded ethanol series, embedded in paraffin, sectioned at $7 \mu \mathrm{m}$ in a rotating microtome and stained with alcian blue and hematoxylin.

For chronic exposure ( $n=7$ per group), animals were obtained from the same supplier, and then exposed for 30 days at concentrations of $0.5 \mathrm{mg} \mathrm{L}^{-1}$ and $4.0 \mathrm{mg} \mathrm{L}^{-1}$ of $\mathrm{MnCl}_{2}$, and to the reconstituted water (negative control). Histological procedures occurred at the end of the 30 day exposure, as previously mentioned for the acute experiment.

The samples from both experiments were analyzed under light microscopy (400x magnification) with a coupled camera to obtain the images (Opton TA- 0124 HD). Fifty fields were analyzed per animal ( $n=7$ per group), where the presence or absence of eosinophils in the intestinal epithelium, infiltration of blood cells, increase in intestinal villi thickness and fusion of intestinal villi were recorded. In addition, for each field the number of goblet cells marked by alcian blue staining was also counted.

For the interpretation of the results, the normality of the data was tested through the Kolmogorov-Smirnov test, for later application of the ANOVA test, followed by the Tukey post-test, when necessary. Pearson's correlation coefficient was also applied, when relevant. All statistical analyses were performed in GraphPad Prism 6 software. 


\section{Results and discussion}

The appearance of morphological changes was observed at the end of the exposure periods, being these significant changes found in the chronic exposure. It is to highlight that no alterations in the assessed water parameters were observed. The histopathological changes and goblet cells analyses can be observed in figure 1. No significant differences were observed in relation to the histopathological changes in the acute experiment, however, there was a tendency of increase histological changes as the $\mathrm{MnCl}_{2}$ increased concentrations (Fig. 2). For the chronic exposure, the fish of the negative control differed significantly from the other groups $(\mathrm{p}=0.004)$, presenting greater percentage of fusion of intestinal villi (Fig. 2 and 3$)$. Other changes did not differ significantly between the groups.

Regarding goblet cell counting (Table 1), in the acute experiment, the negative control group and the concentration of 0.5 $\mathrm{mg} \mathrm{L}{ }^{-1}$ of $\mathrm{MnCl}_{2}$ differed significantly from the concentrations of $8.0 \mathrm{mg} \mathrm{L}^{-1}$ and $16.0 \mathrm{mg} \mathrm{L}^{-1}$, with a lower amount of mucus cells marked by alcian blue $(\mathrm{p}=0.001)$. The Pearson correlation applied in this goblet cell counting (Table 1$)$ revealed a positive correlation between the number of these cells and the increase in $\mathrm{MnCl}_{2}$ concentrations after acute exposure.

Although it is not possible to assess if there is correlation in chronic exposure, it is emphasized that the number of goblet cells recorded in the animals exposed to $4.0 \mathrm{mg} \mathrm{L}^{-1}$ of $\mathrm{MnCl}_{2}$ was relatively higher than in the control group of the same experiment and the animals exposed to the same $\mathrm{MnCl}_{2}$ concentration from acute exposure. Even so, no significant differences were found between the groups of the chronic experiment for counting these cells, suggesting that after chronic exposures to $\mathrm{MnCl}_{2}$ the intestinal epithelium of zebrafish present a more attenuated inflammatory response than after acute exposures.

Figure 1 - Images of intestinal villi of Danio rerio, black and thin arrows indicate goblet cells stained with Alcian Blue. Image A represents the acute exposure control group. In $\mathrm{B}\left(0.5 \mathrm{mg} \mathrm{L}^{-1} \mathrm{MnCl}_{2}\right.$ - acute exposure $)$ the thickness of intestinal villi (|---|) and blood cell infiltrate (red arrow) was observed. In $\mathrm{C}\left(16.0 \mathrm{mg} \mathrm{L}-1\right.$ of $\mathrm{MnCl}_{2}$ - acute exposure), the thick black arrow shows the fusion of the villi. The $\mathrm{D}$ image represents the chronic exposure control group. In $\mathrm{E}\left(0.5 \mathrm{mg} \mathrm{L}^{-1}\right.$ of $\mathrm{MnCl}_{2}-$ chronic exposure) the black arrowhead denotes the presence of eosinophils in the intestinal villi, and the $\mathrm{F}$ image represents the group chronically exposed to $4.0 \mathrm{mg} \mathrm{L}^{-1}$ of $\mathrm{MnCl}_{2}$.
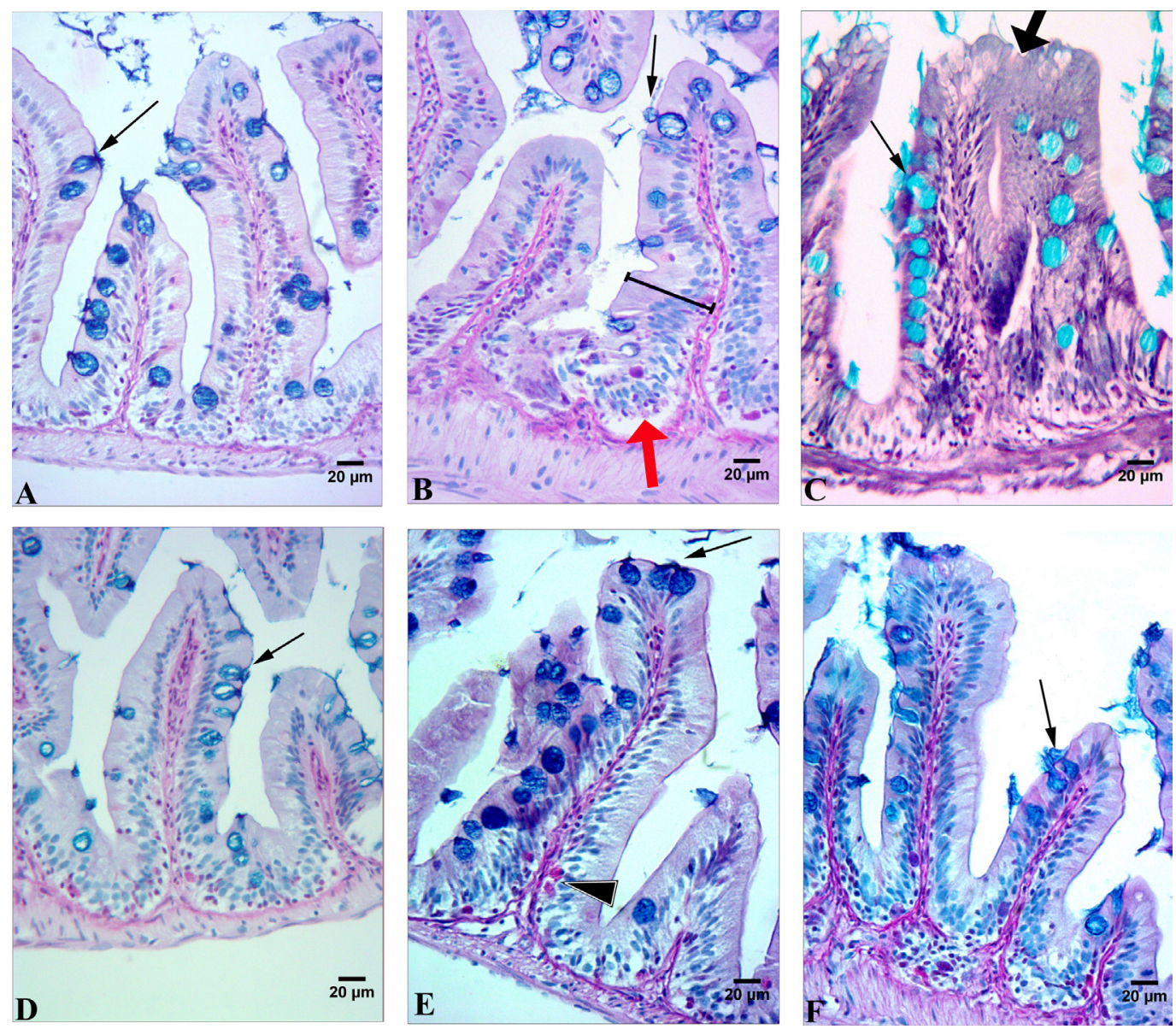
Figure 2 - Graphs representing the \% of villi with histological changes, in relation to the control group (red line), of animals acutely (A) and chronically (B) exposed to $\mathrm{MnCl}_{2}$. Data expressed as mean \pm standard deviation

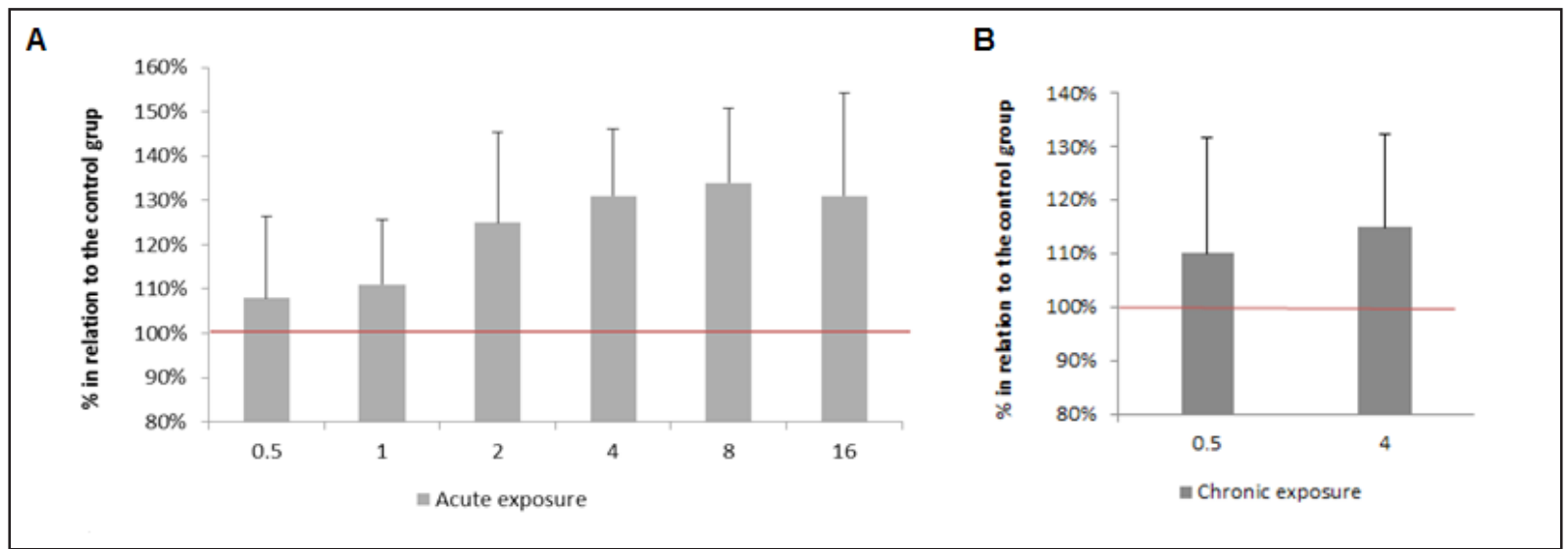

Figure 3 - Graph representing the \% of villous with fusion. (Data expressed as mean \pm standard deviation). * Represent a significant difference in relation to the control

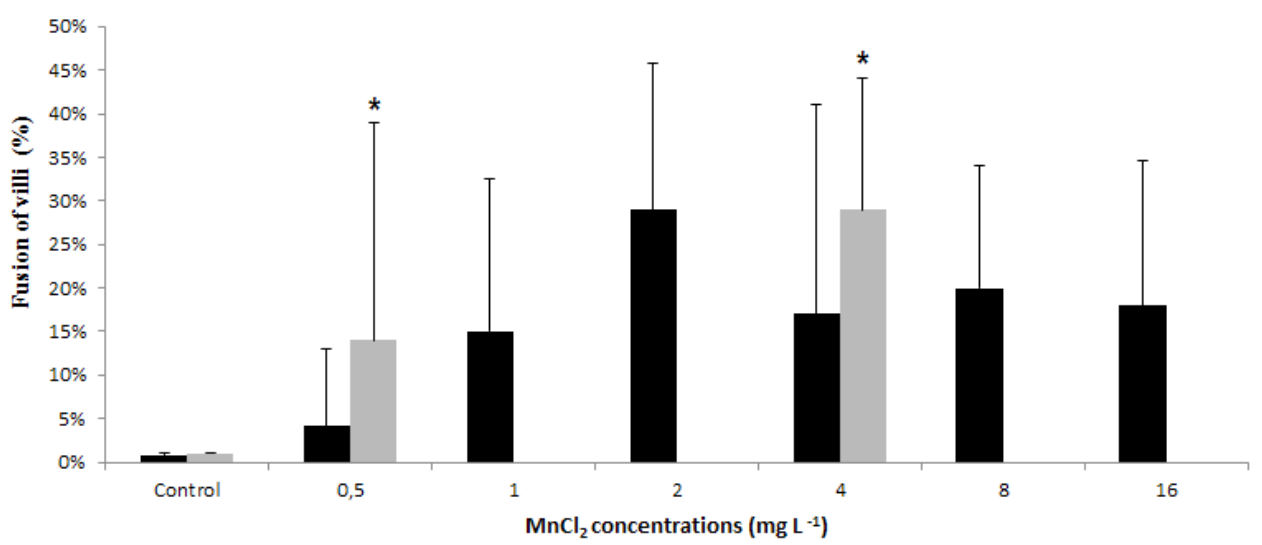

- Acute $=$ Chronic

Table 1 - Table containing Pearson (R) correlation applied between histological changes and $\mathrm{MnCl}_{2}$ concentrations in both exposures (data expressed as percentage), and goblet cell counting. R representing the Pearson correlation applied to the data. Data expressed as mean \pm standard deviation

\begin{tabular}{|c|c|c|c|c|c|c|c|c|c|c|}
\hline & & 递 & 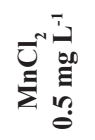 & 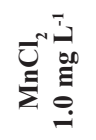 & 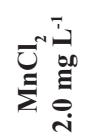 & 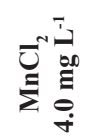 & 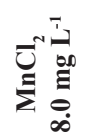 & 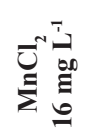 & $=$ & $\simeq$ \\
\hline $\begin{array}{c}\text { Acute } \\
\text { Exposure }\end{array}$ & Eosinophils & $45 \%$ & $70 \%$ & $73 \%$ & $84 \%$ & $89 \%$ & $57 \%$ & $61 \%$ & - & 0.37 \\
\hline $\begin{array}{c}\text { Acute } \\
\text { Exposure }\end{array}$ & Goblet cells & $\begin{array}{c}10.1 \pm \\
3.9^{\mathrm{A}}\end{array}$ & $\begin{array}{c}11.0 \pm \\
1.6^{\mathrm{A}}\end{array}$ & $\begin{array}{l}12.0 \pm \\
4.6^{\mathrm{AB}}\end{array}$ & $\begin{array}{l}9.40 \pm \\
4.8^{\mathrm{AB}}\end{array}$ & $\begin{array}{c}12.3 \pm \\
5.7^{\mathrm{AB}}\end{array}$ & $\begin{array}{c}26.2 \pm \\
9.2^{\mathrm{B}}\end{array}$ & $\begin{array}{c}22.7 \pm \\
6.6^{\mathrm{B}}\end{array}$ & 0.001 & 0.82 \\
\hline $\begin{array}{l}\text { Chronic } \\
\text { Exposure }\end{array}$ & Goblet cells & $\begin{array}{c}10.2 \pm \\
5.4^{\mathrm{A}}\end{array}$ & $\begin{array}{c}14.5 \pm \\
2.5^{\mathrm{A}}\end{array}$ & - & - & $\begin{array}{c}15.9^{ \pm} \\
6.3^{\mathrm{A}}\end{array}$ & - & - & 0.05 & - \\
\hline
\end{tabular}


Histopathological lesions are described as important tools in biomonitoring and ecotoxicological studies due to ease of interpretation, both in acute and chronic exposure situations (SANTOS et al., 2015). However, it is known that the accumulation of metals in different tissues depends mainly on the concentrations and periods of exposure, a fact that can be observed in the present study; villus fusion, and blood cell infiltrate appeared more frequently in fish exposed to higher $\mathrm{MnCl}_{2}$ concentrations at both exposure periods; as well as villus thickness, which shows a tendency to increase in the measurements (data not shown). These histological changes represent inflammatory responses of the intestinal epithelium, which causes concern, since the intestine plays important roles in the digestive system and is, therefore, a key organ for homeostasis of the organism (DOS SANTOS et al., 2016).

The change in the frequency of intestinal eosinophils can occur through changes in the differentiation of eosinophils in the bone marrow, leading to changes in circulating association, migration of these cells from the circulation to a target tissue, and changes in survival longevity within the tissue (SVENSSON-FREJ, 2011). In acute exposure, eosinophils, a kind of multifunctional leukocytes with an important role in parasitic infections and allergic inflammations, were found in a smaller number in the higher concentrations of $\mathrm{MnCl}_{2}$ tested, characterizing an abnormal condition, since these cells appear in greater quantity in the fish gills and intestines, playing an important role in the recovery of lesions (SFACTERIA et al., 2015; DA SILVA et al., 2017). Thus, the reduction in the frequency of these cells can lead to problems in intestinal immunity (CHEN et al., 2015). An inverse response can be observed in fish from chronic exposure to $\mathrm{MnCl}_{2}$, since there was an increase in the frequency of eosinophils at the concentrations tested, characterizing intestinal inflammation (BRUGMAN et al., 2014; WITTE et al., 2014).

Regarding the goblet cell counting, other authors also report the increase of these cells in situations of exposure to various xenobiotics (FLEMING et al., 2010; OEHLERS et al., 2012; DOS SANTOS et al., 2016). These cells participate in the maintenance and development of the intestinal epithelium and secrete mucus, an essential substance for protection against infections, which prevents the contact of microorganisms with intestinal epithelial cells (ROCHA et al., 2016). Increase in mucus production may represent a defense response to exposure to high concentrations of $\mathrm{MnCl}_{2}$, as observed in the acute experiment.

It is known that the presence of pathogens alters the composition of the intestinal microbiota and may induce innate immune responses in zebrafish (YANG et al., 2017). However, few studies report the interference of chemical elements under the intestinal microbiota in the species (AUGUSTINE et al., 2015). In mice, a study reports that prolonged exposure to metals changes the intestinal microbial composition of animals (ZHAI et al., 2017) in a specific way (varying from metal to metal) and dependent on time. The same author reports that lead causes a decline in intestinal microbiota diversity, while an inverse response is observed for animals exposed to cadmium. In order to better understand the mechanisms involved in intestinal damage caused by chronic exposure mainly to $\mathrm{MnCl}_{2}$ in zebrafish, evaluating the intestinal microbiota would be important. Another aspect that should be considered is the route of exposure and absorption of aquatic pollutants such as manganese.

\section{Conclusion}

Based on the results obtained, it is observed that even in acute exposures, high concentrations of $\mathrm{MnCl}_{2}$ can cause changes in the production of mucus-secreting cells and the appearance of histopathological changes in the intestinal epithelium of Danio rerio. Thus, the importance of quantification and removal of this and other metals from the different water bodies is emphasized, aiming to reduce to the maximum the damages that these substances can cause to aquatic biota and human health.

\section{Acknowledgment}

Coordenação de Aperfeiçoamento de Pessoal de Nível Superior (CAPES) for the financial support and the Feevale University for the infrastructure.

\section{References}

AHMED MK, ISLAM S, RAHMAN S, HAQUE MR., ISLAM MM. Heavy metals in water, sediment and some fishes of buriganga river, Bangladesh. International Journal of Environmental Research. 2010;4(2): 321-332.

ALTENHOFEN S, WIPRICH MT, NERY LR, LEITE CE, VIANNA MRMR, BONAN CD. Manganese(II) chloride alters behavioral and neurochemical parameters in larvae and adult zebrafish. Aquatic Toxicology. 2017; $182: 172-183$.

AUGUSTINE S, PEREIRA S, FLORIANI M, CAMILLERI V, KOOJIMAN SALM, GAGNAIRE B, ADAM-

GUILLERMIN C. Effects of chronic exposure to environmentally relevant concentrations of waterborne depleted uranium on the digestive tract of zebrafish, Danio rerio. J. Environ. Radioact. 2015; 142: 45-53. 
BRASIL. Conselho Nacional do Meio Ambiente - CONAMA, 2005 [viewed 25 November 2014]. Resolução CONAMA no 357, de 17 de março de 2005. Dispõe sobre a classificação dos corpos de água e diretrizes ambientais para o seu enquadramento, bem como estabelece as condições e padrões de efluentes, e dá outras providencias. Diário Oficial da República Federativa do Brasil [online], Brasília, 18 mar. pp. 58-63. Available from: http://www.mma.gov.br/port/ conama/res/res05/res35705.pdf

BRUGMAN S, WITTE M, SCHOLMAN RC, KLEIN MR, BOES M, NIEUWENHUIS EE. T lymphocyte-dependent and -independent regulation of Cxcl8 expression in zebrafish intestines J. Immunol. 2014;192: 484-491.

CARVALHO CF, OULHOTE Y, MARTORELLI M, CARVALHO CO, MENEZES-FILHO JA, ARGOLLO N, ABREU $\mathrm{N}$. Environmental manganese exposure and associations with memory, executive functions, and hyperactivity in Brazilian children. Neurotoxicology. 2018.

CHEN L, FENG L, JIANG WD, WU P, ZHAO J, KUANG SY, TANG L, TANG WN, ZHANG YA, ZHOU XQ, LIU Y. Intestinal immune function, antioxidant status and tight junction proteins mRNA expression in young grass carp (Ctenopharyngodon idella) fed riboflavin deficient diet. Fish Shellfish Immunol. 2015;47: 470-84.

DA SILVA WF, SIMÕES MJ, GUTIERRE RC, EGAMI MI, SANTOS AA, ANTONIAZZI MM, SASSO GR, RANZANIPAIVA MJT. Special dyeing, histochemistry, immunohistochemistry and ultrastructure: A study of mast cells/ eosinophilic granules cells (MCs/EGC) from Centropomus parallelus intestine. Fish Shellfish Immunol. 2017;60: 502-8.

DALZOCHIO T, SIMÕES LAR, SOUZA MS, RODRIGUES GZP, PETRY IE, ANDRIGUETTI NB, SILVA GJH, GEHLEN G, SILVA LB. Water Quality Parameters, Biomarkers and Metal Bioaccumulation in Native Fish Captured in the Ilha River, Southern Brazil. Chemosphere. 2017; 189;609-18.

DOS SANTOS HB, VIEIRA L, ALVES SN, THOMÉ RG. Análise do intestino delgado de Danio rerio exposto a organofosforado e detergente: um estudo histológico e morfométrico. Revista Conexão Ciência. 2016;11(2); 51-58.

ERIKSON KM, ASCHNER M. Manganese neurotoxicity and glutamate-GABA interaction. Neurochem Int. 2003;43(45): 475-80.

ERIKSON KM, SYVERSEN T, ASCHNER JL, ASCHNER M. Interactions between excessive manganese exposures and dietary iron-deficiency in neurodegeneration. Environmental Toxicology and Pharmacology. 2005; 19(3); 415-521.

FLEMING A, JANKOWSKI J, GOLDSMITH P. In vivo analysis of gut function and disease changes in a zebrafish larvae model of inflammatory bowel disease: a feasibility study. Inflamm. Bowel Dis. 2010;16; 1162-1172.

GOLUB MS, HOGREFE CE, GERMANN SL, TRAN TT, BEARD JL, CRINELLA FM, LONNERDAL B.

Neurobehavioral evaluation of rhesus monkey infants fed cow's milk formula, soy formula, or soy formula with added manganese. Neurotoxicol Teratol. 2005;27: 615-27.

HARIKUMAR PS, NASIR UP. Ecotoxicological impact assessment of heavy metals in core sediments of a tropical estuary. Ecotoxicol Environ Saf. 2010;73(7): 1742 -1747.

HERMES N, SCHNEIDER RC, MOLIN DD, RIEGEL GZ, COSTA AB, BORBELLINI VA, TORRES JP, MALM O. Environmental pathways and human exposure to manganese in southern Brazil. An. Acad. Bras. Ciênc. 2013;85(4): $1275-88$.

HUREM S, GOMES T, BREDE, DA, MAYER I, LOBERT VH, MUTOLOKI S, GUTZOW KB, TEIEN HC, OUGHTON D, ALESTRÖM P, LYCHE JL. Gamma irradiation during gametogenesis in young adult zebrafish causes

persistent genotoxicity and adverse reproductive effects. Ecotoxicology and Environmental Safety. 2018;154: 19-26.

ISLAM MS, AHMED MK, HABIBULLAH-AL-MAMUM M, HOQUE MF. Preliminary assessment of heavy metal contamination in surface sediments from a river in Bangladesh. Environmental Earth Sciences. 2015; 73(4): 1837-1848. 
ISO; International Organization for Standardization. Water quality - Determination of the acute lethal toxicity of substances to a freshwater fish [Brachydanio rerio Hamilton-Buchanan (Teleostei, Cyprinidae)]. ISO 7346-3: Flowthrough method. 1996. Available: [http://www.iso.org]

NABINGER DD, ALTENHOFEN S, BITENCOURT PER, NERY LR, LEITE CE, VIANNA MRMR, BOANAN CD. Nickel exposure alters behavioral parameters in larval and adult zebrafish. Science of Total Environment. 2018;624: 1623-1633.

NAIR M, JAYALAKSHMY KV, BALACHANDRAN KK, JOSEPH T. Bioaccumulation of toxic metals by fish in a semienclosed tropical ecosystem. Environ Forensics. 2006;7: 197-206.

OEHLERS SH, FLORES MV, HALL CJ, CROSIER KE, CROSIER PH. Retinoic acid suppresses intestinal mucus production and exacerbates experimental enterocolitis Dis. Models Mech. 2012;5: 457-467.

OLIVEIRA MTG, ROLIM SBA, FARIAS PCM, MENEGUZZI A, LUTCKMEI C. Industrial pollution of environmental compartments in the Sinos River Valley, RS, Brasil: Geochemical- Biogeochemical characterization and remote sensing. Water Air Soil Pollution, 2008;192:183-198.

RENIERI EA, SFAKIANAKIS DG, ALEGAKIS AA, SAFENKOVA IV, BUHA A, MATOVIC V, TZARDI M, DZANTIEV BB, DIVANACH P, KENTOURI M, TSATSAKIS M. Nonlinear responses to waterborne cadmium exposure in zebrafish. An in vivo study. Environmental Research. 2017; 157: 173-181.

RIETZLER AC, FONSECA AL, LOPES GP. Heavy metals in tributaries of Pampulha Reservoir, Minas Gerais. Braz. J. Biol. 2001;61(3): 363-370.

ROCHA PMC, BARROS MEG, EVÊNCIO-NETO J. Análise morfométrica da parede intestinal e dinâmica de mucinas secretadas no jejuno de frangos suplementados com probiótico Bacillus subtilis cepa C3102. Pesq. Vet. Bras. 2016; 34(4);312-16.

SALAWU MO, SUNDAY ET, OLOYEDE HOB. Bioaccumulative activity of Ludwigia peploides on heavy metals-contaminated water. Environmental Technology \& Innovation. 2018. 10; 324-334.

SANKAR TV, ZYNUDHEEN AA, ANANDAN R, VISWANATHAN NAIR PG. Distribution of organochlorine pesticides and heavy metal residues in fish and shellfish from Calicut region, Kerala, India. Chemosphere. 2006;65: 583-590.

SANTOS DCM, CUPERTINO, MC, MATTA SLP, OLIVEIRA JA, SANTOS, JAD. Histological alterations in liver and testis of Astyanax aff. bimaculatus caused by acute exposition to zinc. Cores, 2015; 62: 131-141.

SFACTERIA A, BRINES M, BLANK U. The mast cell plays a central role in the immune system of teleost fish. Mol Immunol. 2015; 63: 3-8.

SMITH WS, ESPÍNDOLA ELG, ROCHA O. Environmental gradient in reservoirs of the medium and low Tietê River: limnological differences through the habitat sequence. Acta Limnol. Bras.. 2014;26(1): 73-88.

SUBOTIC S, VISNJIÉ-JEFTIC Z, SPASIC S, HEGEDIS A, KRPO-CETKOVIC J, LENHARDT M. Concentrations of 18 Elements in Muscle, Liver, Gills, and Gonads of Sichel (Pelecus cultratus), Ruffe (Gymnocephalus cernua), and European Perch (Perca fluviatilis) in the Danube River near Belgrade (Serbia). Water Air Soil Pollut, 2015;226: 1-11.

SVENSSON-FREJ M. Immunobiology of intestinal eosinophils - a dogma in the changing? J Innate Immun. 2011;3:565-57.

WHO. World Health Organization. Manganese in drinking-water. 2003. Background document for preparation of WHO Guidelines for drinking-water quality. Geneva.

WITTE M, HUITEMA LF, NIEUWENHUIS EE, BRUGMAN S. Deficiency in macrophage-stimulating protein results in spontaneous intestinal inflammation and increased susceptibility toward epithelial damage in zebrafish. Zebrafish, 2014;11: 542-550. 
YANG HT, ZOU SS, ZHAI LJ, WANG Y, ZHANG FM, AN LG, YANG GW. Pathogen invasion changes the intestinal microbiota composition and induces innate immune responses in the zebrafish intestine. Fish Shellfish Immunol. 2017;71: 35-42.

ZHAI Q, LI T, YU L, XIAO Y, FENG S, WU J, ZHAO J, ZHANG H, CHEN W. Effects of subchronic oral toxic metal exposure on the intestinal microbiota of mice. Sci. Bull. 2017;12: 831-840.

ZHANG S, ZHOU Z, FU J. Effect of manganese chloride exposure on liver and brain mitochondria function in rats. Environ. Res. 2003;93(2): 147-57.

\section{Gabriela Zimmermann Prado Rodrigues \\ Universidade Feevale, RS, Brasil} E-mail: gabizpr@gmail.com

Participação do autor:

\begin{tabular}{l}
\hline Mateus Santos de Souza \\
\hline Universidade Feevale, RS, Brasil \\
E-mail: mateusssouza@yahoo.com.br \\
Participação do autor:
\end{tabular}

\section{Antonia Homrich da Silva}

Universidade Feevale, RS, Brasil

E-mail: antoni.ahds@gmail.com

Participação do autor:

\section{Bruna Graziela Zwetsch}

Universidade Feevale, RS, Brasil

E-mail: bruna.zwetsch23@gmail.com

Participação do autor:

\section{Günther Gehlen}

Universidade Feevale, RS, Brasil

E-mail: guntherg@feevale.br

Participação do autor: 